\title{
PENURUNAN NYERI PASCABEDAH PASIEN TUR PROSTAT MELALUI RELAKSASI BENSON
}

\author{
Gad Datak*, Krisna Yetti**, Rr. Tutik Sri Hariyati**
}

\begin{abstract}
Abstrak
Relaksasi Benson merupakan pengembangan metode respons relaksasi dengan melibatkan faktor keyakinan pasien yang dapat mengurangi nyeri pascabedah. Penelitian ini bertujuan mengetahui efektifitas relaksasi Benson dalam menurunkan nyeri pascabedah pasien TUR Prostat. Metode penelitian quasi-eksperimental dengan pre test and post test design with control group. Pengambilan sampel dengan consecutive sampling. Jumlah sampel 14 orang, masing-masing 7 orang pada kelompok intervensi yang diberikan kombinasi relaksasi Benson dan terapi analgesik serta kelompok kontrol yang hanya diberikan terapi analgesik. Relaksasi Benson dilakukan setelah pemberian analgesik dengan durasi 15 menit selama dua hari. Hasil penelitian menunjukkan kombinasi Relaksasi Benson dan terapi analgesik efektif menurunkan rasa nyeri pascabedah pada pasien TUR Prostat ( $p=0,019, \alpha=0,05$ ). Penelitian ini menyarankan Relaksasi Benson digunakan untuk mengurangi nyeri pasca bedah TUR Prostat elektif.
\end{abstract}

Kata kunci: nyeri pascabedah, relaksasi Benson, TUR prostat

\begin{abstract}
Benson Relaxation is the development of relaxation response method by involving patient is belieffactor to relieve postoperative pain. This research was aimed to explore the effectiveness of Benson Relaxation in relieving post-operative pain of TUR prostate. The method used in this study was quasi experimental with pre test and post test design with control group. A total of 14 consecutive samples were participated in this study by divided into the intervention and control group, 7 participants respectively. Those in intervention group received Benson Relaxation combined with analgesic therapy where as in control group took analgesic therapy alone. Benson Relaxation intervention given after analgesic was taken, for 15 minutes each day for two days. The results revealed that combination between Benson Relaxation and analgesic therapy was more effective than analgesic therapy alone $(p=0,019, \alpha=0,05)$. The Implication of this research was Benson Relaxation can be applied to relieve post-operative pain of elective TUR Prostate.
\end{abstract}

Key words: Benson relaxation, post-operative pain, TUR prostate

\section{PENDAHULUAN}

Giddens (2004) mengatakan bahwa Benigna Prostat Hiperplasia (BPH) merupakan penyebab gangguan dan sumbatan aliran kemih paling banyak dijumpai pada pria lanjut usia. Sebagian pasien $\mathrm{BPH}$ mengalami penyakit ini ketika berusia diatas 50 tahun dan lebih dari $80 \%$ yang mengalami penyakit ini pada usia diatas 80 tahun (Lewis, Heitkemper, \& Dirksen, 2004). Penatalaksanaan jangka panjang yang terbaik pada pasien BPH adalah dengan pembedahan, karena pemberian obat-obatan atau terapi non invasif lainnya membutuhkan waktu sangat lama untuk melihat keberhasilannya.Salah satu tindakan pembedahan yang paling banyak dilakukan pada pasien dengan BPH adalah pembedahan Transurethral Resection of The Prostate (TUR Prostat) (Purnomo, 2007; Smeltzer \& Bare, 2002).
TUR Prostat merupakan prosedur pembedahan dengan memasukkan resektoskopi melalui uretra untuk mengeksisi dan mengkauterisasi atau mereseksi kelenjar prostat yang obstruksi. Prosedur pembedahan TUR Prostat menimbulkan luka bedah yang akan mengeluarkan mediator nyeri dan menimbulkan nyeri pasca bedah (Purnomo, 2007; Smeltzer \& Bare, 2002; Tan, 2007).

Penatalaksanaan nyeri pasca bedah yang tidak tepat dan akurat akan meningkatkan risiko komplikasi, menambah biaya perawatan, memperpanjang hari rawat, dan memperlambat proses penyembuhan (Vaughn, Wichowski, \& Bosworth, 2007). Intervensi keperawatan yang dilakukan perawat untuk mengurangi atau menghilangkan nyeri pascabedah dilakukan dengan pendekatan farmakologis dan nonfarmakologis. 
Intervensi nonfarmakologis merupakan terapi pelengkap untuk mengurangi nyeri pasca bedah dan bukan sebagai penggantiutama terapi analgesik yang telah diberikan.

The Agency for Health Care Policy and Research/ AHCPR (1992) merekomendasikan bahwa kombinasi intervensi farmakologis dan nonfarmakologis merupakan cara terbaik untuk mengontrol nyeri pascabedah (Roykulcharoen, 2003).

Relaksasi Benson merupakan salah satu intervensi nonfarmakologis yang digunakan untuk mengurangi nyeri pasca bedah. Relaksasi Benson merupakan pengembangan metode respons relaksasi dengan melibatkan faktor keyakinan pasien, yang dapat menciptakan suatu lingkungan internal sehingga dapat membantu pasien mencapai kondisi kesehatan dan kesejahteraan lebih tinggi (Benson \& Proctor, 2000).

Hasil penelitian menunjukkan bahwa Relaksasi Benson secara signifikan mengurangi distress dan sensasi nyeri pasca bedah abdominal (cholecystectomy) pada wanita $(\mathrm{p}=0,011, \alpha=0,05)$ (Levin, Malloy, \& Hyman, 1987).

Data rekam medik sebuah RS di Jakarta dari bulan Oktober-Desember 2007 menunjukkan pasien BPH berjumlah 41 kasus diantaranya pada 30 kasus $(73 \%)$ dilakukan bedah TUR Prostat. Penatalaksanaan nyeri pascabedah pada pasien TUR Prostat diRS tersebut relatif sama dengan pelayanan kesehatan rumah sakit lainnya.

Intervensi farmakologis dilakukan dengan pemberian analgesik sesuai dengan standar pelayanan medik. Selain itu, intervensi nonfarmakologis yang digunakan dan tertulis pada rencana perawatan, misalnya meliputi latihan napas dalam, distraksi, dan imajinasi terbimbing. Penelitian ini dilatarbelakangi pertimbangan bahwa pasien TUR Prostat lebih banyak dialami oleh pria lanjut usia yang memiliki pemahaman spiritualitas relatif lebih baik.

Selain itu, belum ada laporan penelitian di Indonesia yang menunjukkan penggunaan Relaksasi Benson untuk mengurangi nyeri pascabedah pasien TUR Prostat. Dengan demikian, perlu diketahui efektifitas Relaksasi Benson untuk menurunkan nyeri pasca bedah pasien TUR Prostat di sebuah RS di Jakarta.

\section{METODE}

Desain penelitian ini adalah kuasi-eksperimen dengan pre test and post test design with control group. Kelompok intervensi memperoleh kombinasi Relaksasi Benson dan terapi analgesik, sedangkan kelompok kontrol hanya memperoleh pemberian analgesik. Populasi penelitian ini adalah seluruh pasien TUR Prostat elektif di sebuah RS di Jakarta. Teknik sampling yang digunakan adalah consecutive sampling. Kriteria inklusiresponden adalah pasien TUR Prostat yang elektif, minimal dirawat 2 hari pascabedah, kesadaran compos mentis dan kooperatif, dengan usia di atas 50 tahun. Selain itu, pasien mendapatkan terapi analgesik Nonsteroidal Antiinflammatory Drugs (NSAIDs) yaitu Ketesse (Dexketoprofen) dan bersedia melakukan Relaksasi Benson. Penelitian dilaksanakan selama bulan April sampai dengan Juni 2008. Jumlah sampel penelitian sebanyak 14 pasien, masing-masing tujuh pasien pada kelompok intervensi dan kontrol.

Relaksasi Benson diajarkan satu hari sebelum operasi dan setelah operasi dilakukan secara mandiri oleh pasien dengan didampingi peneliti. Kombinasi Relaksasi Benson dan terapi analgesik dilakukan satu kali setiap harinya selama dua hari, yaitu pada hari operasi dan hari pertama pasca-operasi dengan durasi 15 menit. Relaksasi Benson dilakukan setelah pasien diberikan terapi analgesik dan dua jam setelah makan. Pengukuran nyeri berupa lapor diri pasien dengan menggunakan skala Numeric Rating Scale (NRS) dengan skala nyeri 0-10 mm yang dilakukan sebelum terapi analgesik. Pasien kembali 30 menit sesudah diberikan kombinasi Relaksasi Benson dan terapi analgesik atau dengan hanya terapi analgesik saja. Pengukuran tingkat kecemasan pasien dilakukan satu hari sebelum operasi dan hari pertama pasca-operasi dengan menggunakan skala kecemasan Visual Analogue Scale (VAS) skala 0$100 \mathrm{~mm}$.

\section{HASIL}

\section{A. Efektifitas Relaksasi Benson}

Ada perbedaan rerata nyeri pascabedah TUR Prostat antara kelompok kontrol dan kelompok intervensi sebelum diberikan terapi analgesik (pra intervensi), setelah operasi (diberikan terapi analgesik), dan pasca operasi hari pertama (tabel1). 
Tabel 1. Rata-Rata Nyeri Pascabedah pada pasien TUR Prostat

\begin{tabular}{ccccc}
\hline No & Responden & Mean & SD & Min-Max \\
\hline 1 & Kel. Kontrol & & & \\
& HOPI & 3,43 & 0,54 & $3-4$ \\
& HO & 2,43 & 0,54 & $2-3$ \\
& POHP1 & 1,71 & 0,49 & $1-2$ \\
2 & Kel.Intervensi & & & \\
& HOPI & 3,57 & 0,79 & $3-5$ \\
& HO & 1,86 & 0,70 & $1-3$ \\
& POHP1 & 1,14 & 0,38 & $1-2$ \\
\hline
\end{tabular}

Keterangan :

HOPI = hari operasi pra intervesi

$\mathrm{HO}=$ hari operasi

POHP1 = pasca operasi hari pertama

Hasil penelitian ini lebih lanjut menunjukkan bahwa pada responden yang menggunakan kombinasi Relaksasi Benson dan terapi analgesik penurunan rasa nyeri pascabedah TUR Prostat lebih tajam dibandingkan dengan pasien yang hanya memperoleh terapi analgesik (grafik 1).

Grafik 1. Perkembangan Rasa Nyeri Pascabedah Pasien TUR Prostat

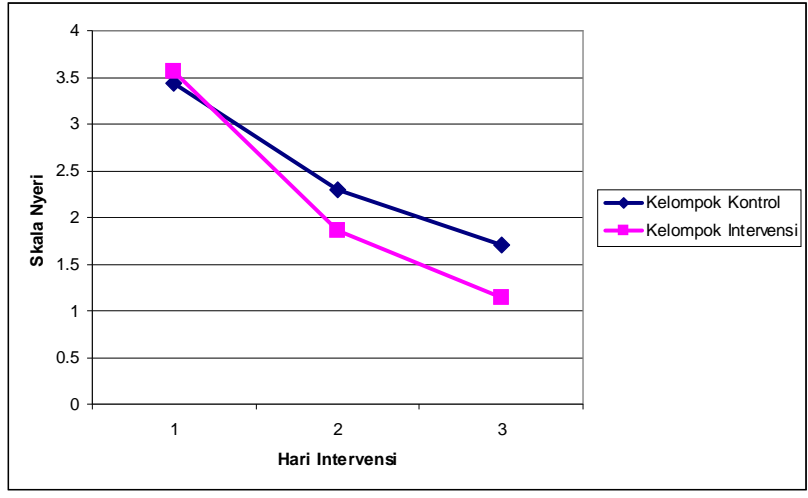

Analisis lebih lanjut seperti pada tabel 2 memperlihatkan ada perbedaan yang bermakna rasa nyeri pascabedah TUR Prostat antara kelompok kontrol dengan kelompok intervensi $(\mathrm{p}=0,019 ; \alpha=$ 0,05). Mean rank kelompok kontrol $(9,50)$ lebih besar dari mean rank kelompok intervensi $(5,50)$.

Hal ini menunjukkan bahwa rasa nyeri pascabedah TUR Prostat pada kelompok intervensi lebih kecil dibandingkan dengan kelompok kontrol. Oleh karena itu, pada pasien pasca TUR Prostat yang dilakukan kombinasi Relaksasi Benson dan terapi analgesik lebih efektif untuk mengurangi nyeri pascabedah dibandingkan dengan hanya diberikan terapi analgesik.
Tabel 2. Beda Nyeri Pascabedah TUR Prostat Sesudah Penatalaksanaan Nyeri pada Kelompok Kontrol dan Kelompok Intervensi

\begin{tabular}{lcccc}
\hline \multicolumn{1}{c}{ Variabel } & $\mathrm{n}$ & $\begin{array}{c}\text { Mean } \\
\text { Rank }\end{array}$ & $\mathrm{z}$ & p Value \\
\hline Nyeri & & & & \\
Kel.Kontrol & 7 & 9,50 & $-2,082$ & 0,019 \\
Kel.Intervensi & 7 & 5,50 & & \\
\hline
\end{tabular}

\section{B. Kontribusi Budaya dan Kecemasan terhadap Nyeri Pascabedah pada Pasien TUR Prostat}

Tabel 3. Kontribusi Budaya dan Kecemasan terhadap Nyeri Pascabedah TUR Prostat pada Kelompok Kontrol dan Kelompok Intervensi

\begin{tabular}{|c|c|c|c|c|c|c|c|}
\hline \multirow[b]{2}{*}{ No } & \multirow[b]{2}{*}{ Variabel } & \multicolumn{3}{|c|}{ Kelp. Kontrol } & \multicolumn{3}{|c|}{ Kelp. Intervensi } \\
\hline & & $\mathrm{N}$ & $\begin{array}{l}\text { Mean } \\
\text { Rank }\end{array}$ & $p$ Value & $\mathrm{n}$ & $\begin{array}{l}\text { Mean } \\
\text { Rank }\end{array}$ & $\begin{array}{c}p \\
\text { Value }\end{array}$ \\
\hline \multirow[t]{5}{*}{1.} & $\begin{array}{l}\text { Latar } \\
\text { Belakang } \\
\text { Budaya }\end{array}$ & & & & & & \\
\hline & Jawa & 2 & 5,00 & & 4 & 4,38 & \\
\hline & Betawi & 2 & 5,00 & 0,202 & 2 & 3,50 & 0,687 \\
\hline & Sunda & 3 & 2,67 & & 0 & 0,00 & \\
\hline & Batak & 0 & 0,00 & & 1 & 3,50 & \\
\hline \multirow[t]{4}{*}{2.} & Cemas & & & & & & \\
\hline & Ringan & 5 & 3,60 & & 6 & 4,08 & \\
\hline & Sedang & 2 & 5,00 & 0,327 & 1 & 3,50 & 0,683 \\
\hline & Berat & 0 & 0,00 & & 0 & 0,00 & \\
\hline
\end{tabular}

Tabel 3 menunjukkan bahwa analisis statistik mean rank pada kelompok kontrol dengan latar belakang budaya Jawa 5,00; Betawi 5,00; dan Sunda 2,67. Sedangkan mean rank pada kelompok intervensi dengan latar belakang Jawa 4,38; Betawi dan Batak adalah sama yaitu 3,50. Hasil analisis lebih lanjut menunjukkan tidak ada kontribusi budaya terhadap rasa nyeri pascabedah TUR Prostat pada kelompok kontrol $(\mathrm{p}=0,202, \alpha=0,05)$ maupun kelompok intervensi $(p=0,687, \alpha=0,05)$.

Tabel 3 memperlihatkan juga variabel kecemasan pada kelompok kontrol dengan mean rank cemas ringan 3,60 dan cemas sedang 5,00. Sedangkan pada kelompok intervensi dengan mean rank cemas ringan 4,08 dan cemas sedang 3,50. Analisis terhadap kecemasan responden terhadap nyeri pascabedah TUR Prostat memperlihatkan perbedaan mean rank kecemasan responden pada kelompok kontrol maupun kelompok intervensi tidak signifikan. 
Analisis lebih lanjut menunjukkan tidak ada kontribusi kecemasan terhadap nyeri pascabedah TUR Prostat pada kelompok kontrol $(\mathrm{p}=0,327, \alpha=$ $0,05)$ maupun kelompok intervensi $(\mathrm{p}=0,683, \alpha=$ $0,05)$. Peneliti menyimpulkan bahwa nyeri pasca bedah TUR Prostat yang dirasakan responden dalam penelitian ini tidak ditentukan oleh kecemasan.

\section{PEMBAHASAN}

Hasil penelitian ini mendukung hasil penelitian sebelumnya bahwa Relaksasi Benson efektif untuk mengurangi rasa nyeripascabedah. Relaksasi Benson dikembangkan dari metode respons relaksasi dengan melibatkan faktor keyakinan (faith factor). Pasien melakukan relaksasi dengan mengulang kata atau kalimat yang sesuai dengan keyakinan responden sehingga menghambat impuls noxius pada sistem kontrol descending (gate control theory) dan meningkatkan kontrol terhadap nyeri.

Hasil penelitian ini juga melaporkan bahwa setelah melakukan relaksasi Benson selama 15 menit, beberapa responden melaporkan rasa tenang dan nyaman. Benson dan Proctor (2000) mengatakan selain mengurangi nyeri pascabedah, Relaksasi Benson menghambat aktifitas saraf simpatik yang mengakibatkan penurunan terhadap konsumsi oksigen oleh tubuh dan selanjutnya otototot tubuh menjadi rileks sehingga menimbulkan perasaan tenang dan nyaman.

Selain itu, Relaksasi Benson berfokus pada kata atau kalimat tertentu yang diucapkan berulang kali dengan ritme teratur dan disertai sikap yang pasrah pada Tuhan Yang Maha Kuasa sesuai keyakinan pasien sehingga memiliki makna menenangkan.

Faktor lain yang diperkirakan oleh peneliti mendukung responden menerima pelaksanaan Relaksasi Benson adalah bahwa seluruh responden penelitian adalah lanjut usia yang diasumsikan memiliki kematangan spiritual yang baik.

Gallup dan Jones (1989) melaporkan suatu survei yang menunjukkan lanjut usia memiliki minat yang kuat terhadap spiritualitas dan berdoa (Nice, 2008). Cupertino dan Haan (1999) menyatakan bahwa lanjut usia yang memilik orientasi religius yang sangat kuat diasosiasikan dengan kesehatan yang lebih baik (Nice, 2008).
Hasil penelitian ini juga memperlihatkan perbedaan mean rank nyeri pascabedah pada pasien TUR Prostat dengan latar belakang budaya tidak signifikan baik pada kelompok kontrol maupun kelompok intervensi. Jadi nyeri pascabedah yang dirasakan responden dalam penelitian ini tidak ditentukan oleh latar belakang budaya mereka.

Hasil ini berbeda dengan pendapat Weber (1996) yang menyatakan budaya etnisitas mempengaruhi persepsi dan ekspresi terhadap nyeri (dalam Denino, 1998). Domisili responden yang umumnya di daerah Jakarta sebagai kota metropolitan dapat menjadi penyebab perbedaan tersebut.

Menurut Suparlan (2004) bahwa kota metropolitan memungkinkan terjadi interaksi budaya dari berbagai suku bangsa sehingga mengakibatkan internalisasi budaya orang lain ke dalam diri responden dan menjadi bagian dari dirinya. Selain itu, responden dilahirkan dari orangtua dengan budaya yang berbeda akan mempengaruhi karakter individu dalam merespon nyeri (Anonimous, 2007).

Menurut Leininger (1999) budaya dapat dipengaruhi oleh kondisi tertentu yang berhubungan dengan faktor lingkungan, bersifat dinamis, dan selalu berubah (dalam Tomey \& Alligood, 2006). Faktorfaktor yang lain selain kemungkinan tersebut perlu penelitian lebih lanjut. Hasil penelitian ini didukung pendapat Smeltzer dan Bare (2002) bahwa hasilhasil riset tidak memperlihatkan suatu hubungan yang konsisten antara nyeri dan kecemasan. Walaupun kecemasan tidak berkontribusi terhadap nyeri pascabedah tetapi hasil penelitian ini juga memperlihatkan bahwa setelah intervensi dilakukan pasien tetap mengalami kecemasan.

Kecemasan yang dialami responden bervariasi baik pada kelompok kontrol maupun kelompok intervensi. Pada kelompok kontrol yaitu kecemasan ringan 5 orang $(71,4 \%)$ dan kecemasan sedang 2 orang $(28,6 \%)$, sedangkan pada kelompok intervensi, yaitu kecemasan ringan 6 orang $(85,7 \%)$ dan kecemasan sedang 1 orang $(14,3 \%)$.

Kecemasan yang terjadi direspon secara khusus dan berbeda oleh setiap responden. Kecemasan yang dialami oleh responden dalam penelitian ini lebih banyak berupa cemas ringan dibandingkan cemas sedang dan tidak ditemukan kecemasan berat. 
Hal ini mungkin dipengaruhi oleh karakteristik responden penelitian yang pada umumnya lansia. Responden lansia diasumsikan mempunyai kemampuan koping yang baik terhadap kecemasan seiring dengan perkembangan kepribadian dan kematangan emosional sehingga lebih adaptif terhadap suatu stresor yang dihadapi (Direktorat Kesehatan Jiwa Depkes RI, 1994). Journal of Personality and Social Psychology (2001) mengatakan bahwa semakin tinggi usia seseorang maka afek-afek positifnya akan lebih banyak. Hal tersebut dikarenakan adanya faktor pendewasaan, pengalaman hidup, dan lain-lainnya (Nice, 2008).

\section{KESIMPULAN}

Hasil penelitian ini dapat digunakan langsung oleh perawat medikal bedah dalam pengelolaan nyeri pascabedah sebagai salah satu intervensi keperawatan mandiri untuk mengurangi rasa nyeri pada pasien setelah menjalani TUR Prostat.

Penelitian ini merekomendasikan Relaksasi Benson sebagai bahan pertimbangan dan digunakan oleh institusi pelayanan keperawatan sebagai salah satu standar operasional prosedur pada pasien yang dilakukan TUR Prostat.

Penelitian juga dapat dikembangkan dengan membandingkan Relaksasi Benson dengan terapi nonfarmakologis yang lainnya dalam menurunkan rasa nyeri pascabedah. Penelitian yang sama dengan jumlah sampel yang lebih besar dan penilaian terhadap tanda-tanda objektif kecemasan perlu dilakukan, karena keterbatasan sampel dan waktu.

Selain itu, dipertimbangkan untuk mengkaji lebih lanjut variabel-variabel lain yang diperkirakan akan berpengaruh terhadap nyeri pasca bedah seperti pengalaman terhadap nyeri, faktor-faktor infeksi pada pasien $\mathrm{BPH}$, dan besarnya reseksi terhadap massa prostat (TN, FH).

* StafAkademik Jurusan Keperawatan Politeknik Kesehatan Palangkaraya

** Staf Akademik Kelompok Keilmuan Dasar Keperawatan dan Keperawatan Dasar FIK UI

\section{KEPUSTAKAAN}

Benson, H., \& Proctor, W. (2000). Dasar-dasar respon relaksasi: Bagaimana menggabungkan respon relaksasi dengan keyakinan pribadi anda (alih bahasa oleh Nurhasan). Bandung: Kaifa.

Denino, V. P. (1998). Patient satisfaction with acute pain management. Diperoleh dari http:/ /proquest.umi.com/pqdweb.

Direktorat Kesehatan Jiwa Depkes RI. (1994). Perawatan pasien yang merupakan kasuskasus psikiatri. Jakarta: Depkes RI.

Giddens, J.F. (2004). Nursing management: Male reproductive problems, dalam Lewis, S. M., Heitkemper, M.M., Dirksen, S.R. (2004). Medical surgical nursing: Assesment \& management of clinical problems (volume 2, 6th edition) (hlm.1435-1461). St.Louis: Mosby.

Lantas Metro. (2007). Dinamika dan potensi konflik pada masyarakat kota metropolitan. Diperoleh dari http://www.lantas.metro.polri. go.id.

Levin, R.F., Malloy,G.B., \& Hyman, R.B. (1987). Nursing management of postoperative pain: Use of relaxation techniques with female choecystectomy patients, diunduh 10 Pebruari 2008 dari http://www.blackwell-synergy.com.

Nice. (2008). Penyesuaian diri lansia: Perkembangan emosi. Diperoleh dari http:// manejemen.blogspot.com.

Purnomo, B.B. (2007). Dasar-dasar urologi (Edisi kedua). Jakarta: Sagung Seto.

Roykulcharoen, V. (2003). The effect of systemic relaxation technique on postoperative pain in Thailand. Diperoleh dari http:// proquest.umi.com.

Smeltzer, S.C., \& Bare, B.G.. (2002). Buku ajar buku keperawatan medikal bedah Brunner \& Suddarth (Vol 1, Edisi 8, Alih bahasa Agung Waluyo, et al.). Jakarta: EGC.

Smeltzer, S.C., \& Bare, B.G.. (2002). Buku ajar buku keperawatan medikal bedah Brunner \& Suddarth (vol 2, edisi 8, Alih bahasa Kuncara, H.Y., et al). Jakarta: EGC. 
Tomey, A,M. \& Alligood, M,R. (2006). Nursing theorists and their work. 6th edition. St. Louis: Mosby.

Tan, J.K.N. (2007) Pulihkan prostat dengan laser hijau, Majalah Senior, diunduh 10 Pebruari 2008 dari http://cybermed.cbn.net.id.
Vaughn, F., Wichowski, H., \& Bosworth,G. (2007). Does preoperative anxiety level predict postoperative pain. AORN Journal, 85 (3), 589-604.

Bukan kurangnya pengetahuan yang menghalangi keberhasilan, tetapi tidak cukupnya tindakan.

Dan bukan kurang cerdasnya pemikiran yang melambatkan perubahan hidup ini, tetapi kurangnya penggunaan dari pikiran dan kecerdasan.

- Mario Teguh -

Ketika berusaha maksimal,

kita tidak akan pernah tahu keajaiban apa yang akan datang pada kita atau orang lain.

- Hellen Keller -

Orang-orang yang bekerja keras hari ini dan memastikan bahwa yang dilakukannya hari ini pantas mendapat penghargaan di masa depan, akan bisa lebih senang nanti menyambut masa depan yang datang dengan kualitas yang lebih baik.

- MT Star Point-

Orang-orang yang sukses telah belajar membuat diri mereka melakukan hal yang harus dikerjakan ketika hal itu memang harus dikerjakan, entah mereka menyukainya atau tidak.

- Aldus Huxley -

Apa yang nampak sebagai suatu kemurahan hati, sering sebenarnya tiada lain daripada ambisi yang terselubung,

yang mengabaikan kepentingan-kepentingan kecil untuk mengejar kepentingan- kepentingan yang lebih besar.

- La Roucefoucauld - 